\title{
TINGKAT KEPUASAN PASIEN TERHADAP PELAYANAN KEFARMASIAN DI PUSKESMAS SUNGAI RANGIT DAN PUSKESMAS NATAI PELINGKAU KABUPATEN KOTAWARINGIN BARAT
}

\author{
Rahman Nur Chabib'; Yogie Irawan²; Ahmad Irawan ${ }^{3}$ \\ ${ }^{1,2,3}$ Stikes Borneo Cendekia Medika Pangkalan Bun \\ Email: rahmannurchabib@gmail.com
}

\begin{abstract}
ABSTRAK
Kepuasan yaitu dimana perasaan seseorang yang muncul setelah membandingkan antara kinerja dan kualitas jasa pelayanan yang didapat dengan keinginan, kebutuhan dan harapan. Tujuan penelitian ini untuk men3hui tingkat kepuasan pasien terhadap pelayanan kefarmasian di Puskesmas Sungai Rangit dan Puskesmas Natai Pelingkau Kabupaten Kotawaringin Barat. Penelitian ini menggunakan desain penelitian bersifat deskriptif, teknik pengambilan sampel teknik purposive sampilng. Sampel penelitian sebanyak 60 responden pada kedua Puskesmas Sungai Rangit dan Puskesmas Natai Pelingkau. Pengambilan data dilakukan melalui pengisian kuesioner yang telah di uji validitas dan realibilitasnya saja waktu tunggu yang dilakukan dengan menggunakan stopwacth. Data analisis dibuat tabulasi, dihitung menggunakan rumus presentase, dan waktu tunggu menggukan rata-rata pelayanan resep untuk melihat perbedaan waktu tunggu obat jadi dan obat racikan serta melihat waktu perbedaan kedua Puskesmas. Hasil penelitian menunjukan bahwa tingkat kepuasan persentase ratarata secara keseluruhan sebesar (86\%) pada Puskesmas Sungai Rangit dan (85\%) pada Puskesmas Natai Pelingkau dengan kategori kepuasan adalah sangat puas. Hasil penelitian tentang waktu tunggu pelayanan resep memiliki rata-rata waktu tunggu resep racikan 13 menit pada kedua Puskesmas sedangkan waktu tunngu resep obat non racikan adalah 6 menit pada kedua Puskesmas. berdasarkan hasil penelitian diperoleh bahwa tingkat kepuasan pasien terhadap pelayanan kefarmasian di Puskesmas Sungai Rangit dan Puskesmas Natai Pelingkau dalam Kategori sangat puas.
\end{abstract}

Kata Kunci: Tingkat kepuasan, waktu tunggu, Deskriptif, Puskesmas.

\section{ABSTRACK}

Satisfaction is person's feelings after comparing the performance and service quality with wishes, needs, and expectations. The purpose of this study is to determine the level of patient satisfaction to pharmaceutical services in Puskesmas Sungai Rangit and Puskesmas Natai Pelingkau Kabupaten Kotawaringin Barat. This study used descriptive research design, sampling methods used technique purpose sampling. The research sample 60 respondents for both Puskesmas. Data collected thecnique was in questionnaires that have been tested for validity and reliability. The waiting time measured by using stopwatch. Tabulated data in data analysis, calculated using a percentage 
formula, and the waiting time using the average prescription service to show the difference in waiting time. The results of this study shows the level of satisfaction for average percentage is $86 \%$ to Puskesmas Sungai Rangit and $85 \%$ to Puskesmas Natai Pelingkau and is considered very satisfied. The results in this study the avarage tine spent in waiting for the compounded drugs is 16 minutes and non-compounded drugs is 6 minutes for both puskesmas. Based on the results of the study, it was found that the level of patient satisfaction with pharmaceutical services at Puskesmas Sungai Rangit and Puskesmas Natai Pelingkau was in the very satisfied category.

Keywords : Level of Satisfactions, Waiting Time, Descriptif, Puskesmas.

\section{PENDAHULUAN}

Kesehatan seluruh warga negara Indonesia dilindungi oleh konstitusi seperti yang tercantum dalam Undang Undang Dasar 1945 pasal 27 ayat kedua dimana setiap warga negara berhak atas pekerjaan, kesehatan dan penghidupan yang layak bagi kemanusiaan. Dalam rangka mewujudkan status kesehatan masyarakat yang optimal maka berbagai upaya harus dilaksanakan, salah satunya menyelenggarakan pelayanan kesehatan (UUD 1945 Pasal 27 Ayat 2). Sarana pelayanan kesehatan dasar yang amat penting di Indonesia ialah Pusat Kesehatan Masyarakat (Puskesmas).

Standar kepuasan pasien di pelayanan kesehatan ditetapkan secara Nasional oleh Departemen Kesehatan Menurut Peraturan Kementerian Kesehatan Republik Indonesia Tahun 2016 tentang Standar Pelayanan Minimal untuk kepuasan pasien yaitu diatas 95\% (Kemenkes,2016). Bila ditemukan pelayanan kesehatan dengan tingkat kepuasan pasien berada dibawah 95\% maka dianggap pelayanan kesehatan yang diberikan tidak memenuhi standar minimal atau tidak berkualitas.

Penelitian sebelumnya dilakukan oleh Maria Santriatsi
Bupu (2018) berdasarkan tentang tingkat kepuasan pasien terhadap pelayanan kefarmasian di puskesmas di daerah Kota Kupang. Berdasarkan hasil penelitian menunjukkan untuk penilaian yaitu berdasarkan pada standar pelayanan kefarmasian di dapatkan lima dimensi Assurance (Jaminan) di dapatkan nilai sebesar 79,90\%, dimensi Emphaty (Empati) di dapatkan nilai sebesar $72,46 \%$, untuk dimensi Responsivenss (ketanggapan) di dapatkan nilai sebesar $71,35 \%$, dimensi Realiability (Kehandalan) sebesar $71 \%$, sedangkan nilai dimensi Tangible (Bukti fisik) sebesar 62,92\%, berdasarkan nilai rata-rata waktu pelayanan obat sudah memenuhi standar yang ditetapkan oleh SPM Puskesmas Bidang Farmasi, untuk resep obat jadi kurang dari 30 menit dan resep obat racikan kurang dari 60 menit.

Jumlah penduduk Kabupaten Kotawaringin Barat berdasar hasil proyeksi penduduk terhadap data Sensus Penduduk 2010 adalah 286.714 jiwa dengan laju pertumbuhan sebesar 3,23 persen. Meskipun terjadi penurunan jumlah tenaga medis dokter di tahun 2016, namun rujukan penduduk Kotawaringin Barat untuk berobat jalan di fasilitas kesehatan masih terbilang tinggi. Di wilayah 
pedesaan, praktik dokter/bidan sebagai rujukan berobat mencapai 34,34 persen, sementara di wilayah perkotaan sebesar 30,84 persen. Hal ini menunjukkan bahwa masyarakat semakin sadar untuk menggunakan tenaga kesehatan terdidik sebagai penolong kesehatan utamanya di wilayah perdesaan. Selain itu, berdasarkan data hasil Survei Sensus tahun 2016, Puskesmas mengalami peningkatan yang cukup tinggi sebagai rujukan masyarakat untuk berobat yaitu sebesar 40,95 persen (Dinkes, 2018).

Keberhasilan pemerintah daerah dalam program kesehatan dan program pembangunan sosial ekonomi pada umumnya dapat dilihat dari peningkatan usia harapan hidup penduduknya. Usia harapan hidup ditentukan oleh besarnya angka kematian bayi di suatu kabupaten/kota. Jika dilihat, selama kurun waktu 3 tahun, angka harapan hidup di Kotawaringin Barat mengalami peningkatan hingga di tahun 2016 mencapai 70,21 tahun. Hal ini menunjukkan keberhasilan pemerintah menurunkan angka kematian bayi melalui berbagai program kesehatan, seperti imunisasi dan perbaikan lingkungan perumahan (Dinkes, 2018).

Hasil dari penelitian ini akan dapat digunakan sebagai acuan dalam memperoleh informasi tentang tingkat kepuasan pasien terhadap pelayanan kefarmasian di Puskesmas Sungai Rangit dan Puskesmas Natai Pelingkau Kabupaten Kotawaringin Barat 2020.

\section{METODE PENELITIAN}

Penelitian ini menggunakan metode deskriptif, menggunakan desain penelitian Purposive sampling

\section{Populasi dan Sampel}

populasi dalam penelitian ini adalah pasien rawat jalan yang berobat di Puskesmas Sungai Rangit dan Puskesmas Natai Pelingkau Kabupaten Kotawaringin Barat sebanyak 60 sampel.

\section{Kriteria inklusi dan eksklusi}

1. Kriteria inklusinya adalah:

a) Pasien yang berobat di Puskesmas Sungai Rangit dan Puskesmas Natai Pelingkau Kabupaten Kotawaringin Barat

b) Bersedia menjadi responden

c) Terdaftar sebagai pasien

d) Dewasa berkisar umur 17 - 65 Tahun

2. Sedangkan kriteria eksklusi yaitu:

a) Tidak bersedia menjadi responden

b) Tidak menebus obat dan memiliki gangguan dalam berkomunikasi

\section{Pengambilan data}

Instrumen yang digunakan dalam penelitian ini pada variabel independen dan variabel dependen adalah dengan mengajukan kuesioner yaitu beberapa daftar pertanyaan tertulis yang sudah disiapkan dan jawabannya secara tertutup yang digunakan untuk memperoleh data/informasi dari responden dalam arti laporan tentang pribadinya, atau hal-hal yang di ketahui dan dipahaminya bisa menggunkan bahasa yang sesuai agar lebih mudah dimengerti (Arikurto, 2017). Selanjutnya untuk melakukan pengukuran waktu tunggu pelayanan resep digunakan alat ukur berupa Stopwatch dan instrument yang digunakan untuk mengolah data tersebut menggunakan aplikasi Statistical Package for the Social 
Science atau yang sering disebut SPSS.

\section{Analisis data}

Kegiatan setelah data dari seluruh responden atau data lain terkumpul. Kegiatan dalam analisis data adalah mengelompokan data berdasarkan variabel dan jenis responden, mentabulasi data berdasarkan variabel dari seluruh responden, menyajikan data tiap variabel yang ditiliti, melakukan perhitungan untuk hipotesis yang telah diajukan (sugiyono, 2016)

Tabulating, adalah pengumpulan data jawaban dengan teratur dan teliti, kemudian dihitung dan dijumlahkan serta disajikan dalam bentuk tabel. Pengukuran kepuasan dilakukan dengan menghitung persentase masingmasing indikator pertanyaan (responsiveness, reliability, emphaty assurance, dan tangibles). Dengan menggunakan rumus (Sugiyono, 2017).

Tingkat kepuasan :
$\sum \frac{\text { skor perolehan }}{\text { skor maksimum }} \times 100 \%$
Berdasarkan rumus tersebut
dapat disesuaikan dengan range
skala tingkat kepuasan pasien
sebagai berikut:

\begin{tabular}{lcl}
\hline No & $\begin{array}{c}\text { Tingkat } \\
\text { Kepuasan }\end{array}$ & \multicolumn{1}{c}{$\begin{array}{c}\text { Nilai skala } \\
\text { Peringkat }\end{array}$} \\
\hline 1 & SP & $81-100 \%$ \\
2 & $\mathrm{P}$ & $61-80 \%$ \\
3 & $\mathrm{CP}$ & $41-60 \%$ \\
4 & $\mathrm{TP}$ & $<40 \%$ \\
\hline
\end{tabular}

Rumus rata-rata (Mean):

$\mathrm{X}=\sum \mathrm{X} / \mathrm{N}$

Keterangan :

$\mathrm{X}=$ waktu rata-rata $\sum \mathrm{X} \underset{\text { pelayanan }}{=}$ jumlah waktu

$\mathrm{N} \quad$ = jumlah resep

Penilaian kecepatan pelayanan resep ini dikatakan memenuhi persyaratan Keputusan Menteri Kesehatan Republik Indonesia Nomor 129/Menkes/SK/II/2008 tentang standar pelayanan rumah sakit apabila :

1. Untuk resep obat jadi, memenuhi persyaratan apabila kecepatan waktu pelayanan $\leq 30$ menit.

2. Untuk resep obat racikan, memenuhi persyaratan apabila kecepatan waktu pelayanan $\leq 60$ menit.

\section{HASIL DAN PEMBAHASAN}

Karakteristik Responden

Berdasarkan data diagram karakteristik dapat dilihat dari penyebaran kuesioner berdasarkan jenis kelamin bahwa sebagian besar pasien yang menjadi responden berjenis kelamin perempuan $(63,3 \%)$ pada Puskesmas Sungai Rangit dan (70\%) pada Puskesmas Natai Pelingkau. Sedangkan untuk pasien yang laki-laki sebesar $(37,6 \%)$ pada Puskesmas Sungai Rangit dan (30\%) pada Puskesmas Natai Pelingkau.

Tabel 5.1 Analisa Distribusi Responden Jenis Kelamin berdasarkan jenis kelamin di Puskesmas Sungai Rangit dan Pekesmas Natai Pelingkau Periode Januari - Februari 2020 


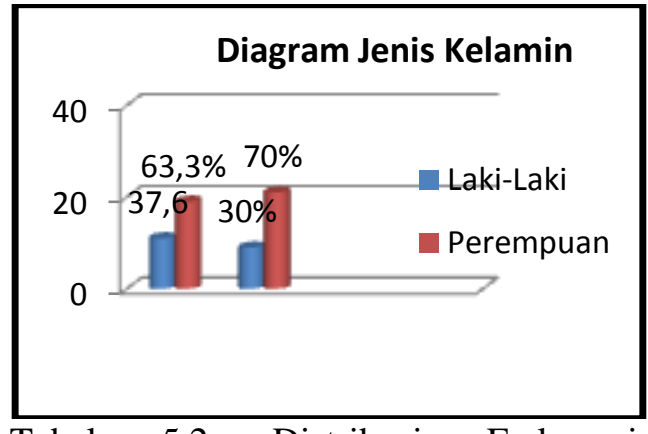

Tabel 5.2 Distribusi $\quad$ Frekuensi Karakterisitik Umur Responden di Puskesmas Sungai Rangit dan Puskesmas Natai Pelingkau pada bulan Januari - Februari 2020

\begin{tabular}{ccccc}
\hline \multirow{2}{*}{ Umur } & \multicolumn{2}{c}{$\begin{array}{c}\text { Puskesmas } \\
\text { Sungai } \\
\text { Rangit }\end{array}$} & \multicolumn{2}{c}{$\begin{array}{c}\text { Puskesmas } \\
\text { Natai } \\
\text { Pelingkau }\end{array}$} \\
\cline { 2 - 5 } & $\mathbf{N}$ & $\mathbf{\%}$ & $\mathbf{N}$ & $\boldsymbol{\%}$ \\
\hline $17-27$ & 7 & $23,3 \%$ & 9 & $30,0 \%$ \\
$28-38$ & 17 & $56,7 \%$ & 15 & $50,0 \%$ \\
$39-49$ & 6 & $20,0 \%$ & 6 & $20,0 \%$ \\
\hline
\end{tabular}

Berdasarkan Tabel 5.2 dibawah menunjukkan bahwa persentase tertinggi pada umur 28-38 Tahun (56,7\%) pada Puskesmas Sungai Rangit dan (50,0\%) pada Puskesmas Natai Pelingkau. Sampel terendah pada umur 39-49 tahun (20\%) pada Puskesmas Sungai Rangit dan (20\%) pada Puskesmas Natai Pelingkau.

Tabel 5.3 Distribusi Frekuensi Karakterisitik Pendidikan Responden di Puskesmas Sungai Rangit dan Puskesmas Natai Pelingkau pada bulan Januari - Februari 2020

\begin{tabular}{lcccc}
\hline \multirow{2}{*}{$\begin{array}{c}\text { Pendidika } \\
\text { n }\end{array}$} & \multicolumn{2}{c}{$\begin{array}{c}\text { Puskesma } \\
\text { s Sungai } \\
\text { Rangit }\end{array}$} & \multicolumn{2}{c}{$\begin{array}{c}\text { Puskesma } \\
\text { P Natai } \\
\text { Pelingkau }\end{array}$} \\
\cline { 2 - 5 } & $\mathbf{N}$ & $\mathbf{\%}$ & $\mathbf{N}$ & $\mathbf{\%}$ \\
\hline SMA & 11 & $36,7 \%$ & 14 & $46,7 \%$ \\
SMP & 11 & $36,7 \%$ & 8 & $26,7 \%$ \\
Tidak & 4 & $13,3 \%$ & 1 & $3,3 \%$ \\
Tamat SD & & & \\
SD & 4 & $13,3 \%$ & 5 & $16,7 \%$ \\
Perguruan & 0 & $0 \%$ & 2 & $6,7 \%$ \\
Tinggi & & & & \\
\hline
\end{tabular}

Berdasarkan dari hasil penelitian bahwa, pendidikan terakhir responden yang paling besar adalah pendidikan menengah keatas (SMA) dengan nilai $(36,7 \%)$ dari 30 responden pada Puskesmas Sungai Rangit dan (46,7\%) dari 30 responden pada Puskesmas Natai Pelingkau. Pendidikan seseorang akan mempengaruhi perubahan tingkah laku, semakin tinggi pendidikan seseorang maka akan semakin banyak pengetahuan serta informasi yang didapat tentang kesehatan ataupun informasi lain.

Tabel 5.4 Distribusi Frekuensi Karakterisitik Pekerjaan Responden di Puskesmas Sungai Rangit dan Puskesmas Natai Pelingkau pada bulan Januari - Februari 2020

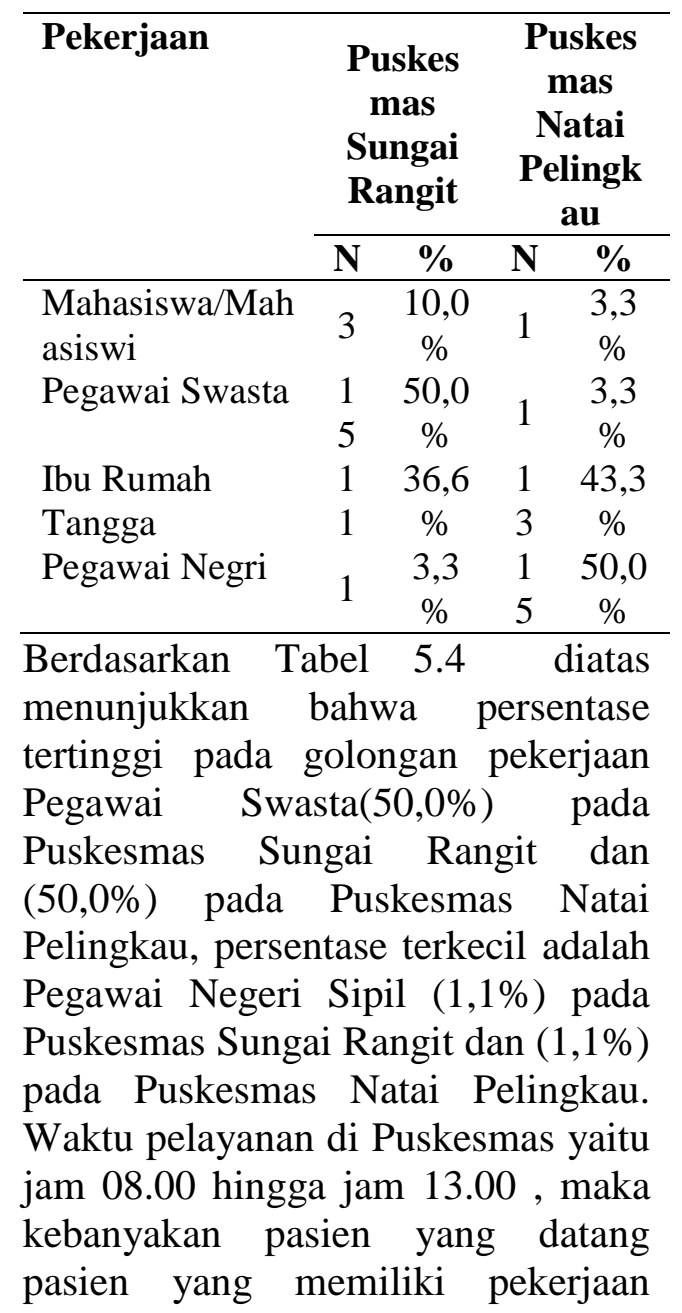


swasta dengan jam yang tidak terikat, ibu rumah tangga/ tidak bekerja sehingga bisa meluangkan waktu untuk berobat.

\section{Tingkat Kepuasan Pasien}

Secara keseluruhan, dari hasil penelitian dapat dikatakan bahwa tingkat kepuasan pasien terhadap pelayanan kefarmasian secara umum di Puskesmas Sungai Rangit dan Puskesmas Natai Pelingkau adalah sangat puas, berdasarkan skor menurut Skala Likert.

Tabel 5.9 Hasil Presentase kuesioner kepuasan pasien di Puskesmas Sungai Rangit dan Puskesmas Natai Pelingkau periode Januari - Februari 2020

\begin{tabular}{|c|c|c|c|}
\hline Indikator & $\begin{array}{c}\text { Puskes } \\
\text { mas } \\
\text { Sungai } \\
\text { Rangit }\end{array}$ & $\begin{array}{c}\text { Puskes } \\
\text { mas } \\
\text { Natai } \\
\text { Pelingk } \\
\text { au }\end{array}$ & $\begin{array}{c}\text { Klasifi } \\
\text { kasi } \\
\text { Kepuas } \\
\text { an }\end{array}$ \\
\hline & Skor \% & Skor \% & \\
\hline $\begin{array}{l}\text { Kehanda } \\
\text { lan }\end{array}$ & $78 \%$ & $78 \%$ & Puas \\
\hline $\begin{array}{l}\text { Ketangg } \\
\text { apan }\end{array}$ & $82 \%$ & $81 \%$ & $\begin{array}{c}\text { Sangat } \\
\text { Puas }\end{array}$ \\
\hline Jaminan & $86 \%$ & $85 \%$ & $\begin{array}{c}\text { Sangat } \\
\text { Puas }\end{array}$ \\
\hline Empati & $82 \%$ & $82 \%$ & $\begin{array}{l}\text { Sangat } \\
\text { Puas }\end{array}$ \\
\hline $\begin{array}{l}\text { Bukti } \\
\text { Fisik }\end{array}$ & $83 \%$ & $83 \%$ & $\begin{array}{l}\text { Sangat } \\
\text { Puas }\end{array}$ \\
\hline $\begin{array}{l}\text { Rata- } \\
\text { Rata }\end{array}$ & $82 \%$ & $81 \%$ & $\begin{array}{l}\text { Sangat } \\
\text { Puas }\end{array}$ \\
\hline
\end{tabular}

Berdasarkan tabel dapat disimpulkan bahwa dari 30 responden pada Puskesmas Sungai Rangit dan 30 responden pada Puskesmas Natai Pelingkau persentase tertinggi yang didapat setiap Puskesmas adalah dimensi Jaminan dengan nilai (86\%) pada Puskesmas Sungai Rangit dan (85\%) pada Puskesmas Natai Pelingkau.
Nilai terendah pada Puskesmas Sungai Rangit terdapat pada dimensi Kehandalan dengan nilai (78\%) dan nilai terendah pada Puskesmas Natai Pelingkau adalah dimensi Kehandalan(Reliability) dengan nilai (78\%). Pada Penelitian Kualitas pelayanan di Puskesmas Berastagi di temukan bahwa dimensi Kehandalan kurang memuaskan dengan Persentase 0,40\% (Ginting, 2012). Berdasarkan Penelitian oleh (Ginting, 2012) menghasilkan bahwa terdapat satu item dimensi Kehandalan yang memuaskan yaitu item pelayanan yang tidak berbelitbelit. Selain item tersebut, item-item dimensi kehandalan pada Puskesmas Berastagi dinyatakan kurang memuaskan menurut persepsi pasien. sedangkan nilai terendah pada kedua Puskesmas Sungai Rangit dan Puskesmas Natai Pelingkau ini diatas $61 \%$ yang artinya tingkat kepuasan pasien tersebut puas.

Waktu Tunggu Pelayanan Obat Jadi dan Obat Racikan pasien rawat jalan di Puskesmas

Dari hasil pengumpulan data diperoleh jumlah sebanyak 30 resep yang terdiri dari obat jadi dan resep obat racik. Dari 30 resep, Obat non racikan berjumlah $69,3 \%$ (21 resep), sedangkan obat racik berjumlah $30,7 \%$ ( 9 resep).

Tabel 5.20 Jumlah sampel berdasarkan jenis resep racikan dan non racikan yang di layani di apotek Puskesmas Sungai Rangit.

\begin{tabular}{lccc}
\hline No & Resep & Sampel & Presentase \\
\hline 1 & Racikan & 9 & $30,7 \%$ \\
2 & Non & 21 & $69,3 \%$ \\
& Racikan & & \\
\hline & Total & 30 & $100 \%$
\end{tabular}

Dari hasil pengumpulan data diperoleh jumlah sebanyak 30 resep yang terdiri dari obat jadi dan resep obat racik. Dari 30 resep, Obat non 
racikan berjumlah $59,7 \%$ (19 resep), sedangkan obat racik berjumlah $40,3 \%$ ( 11 resep).

Tabel 5.21 Jumlah sampel berdasarkan jenis resep racikan dan non racikan yang di layani di apotek Puskesmas Natai Pelingkau.

\begin{tabular}{lccc}
\hline No & Resep & Sampel & Presentase \\
\hline 1 & Racikan & 11 & $40,3 \%$ \\
2 & Non & 19 & $59,7 \%$ \\
& Racikan & & \\
\hline Total & 30 & $100 \%$
\end{tabular}

Berdasarkan hasil pengamatan dan wawancara dengan apoteker dan tenaga teknis Kefarmasian di puskesmas, jumlah resep obat racikan lebih sedikit dibandingkan dengan resep obat non racikan. Hal ini dikarenakan pasien anak-anak jumlahnya lebih sedikit daripada jumlah pasien orang dewasa. Resep untuk anak sebagian besar merupakan resep obat racikan.

Berdasarkan hasil penelitian ini dapat diketahui bahwa rata - rata waktu tunggu pelayanan resep yaitu 13 menit untuk resep racikan di kedua Puskesmas dan 6 menit untuk obat non racikan di Puskesmas Sungai Rangit, 6 menit untuk obat non racikan di Puskesmas Natai Pelingkau

Tabel 5.22 Waktu Tunggu Resep Puskesmas Sungai Rangit

\begin{tabular}{|c|c|c|c|c|}
\hline \multirow[b]{2}{*}{$\begin{array}{c}\text { Jenis } \\
\text { Rese } \\
\mathrm{p}\end{array}$} & \multirow[b]{2}{*}{$\begin{array}{c}\text { Juml } \\
\text { ah } \\
\text { Rese } \\
\text { p }\end{array}$} & \multirow{2}{*}{$\begin{array}{c}\text { Juml } \\
\text { ah } \\
\text { Wak } \\
\text { tu } \\
\text { Tung } \\
\text { gu } \\
\text { (Me } \\
\text { nit) }\end{array}$} & \multicolumn{2}{|c|}{$\begin{array}{c}\text { Rata-Rata } \\
\text { Waktu Tunggu } \\
\text { (Menit) }\end{array}$} \\
\hline & & & $\begin{array}{c}\text { Dari } \\
\text { Hasil } \\
\text { Peneli } \\
\text { tian }\end{array}$ & $\begin{array}{c}\text { Standa } \\
\text { r } \\
\text { Pelaya } \\
\text { nan } \\
\text { Minim } \\
\text { al } \\
\end{array}$ \\
\hline $\begin{array}{l}\text { Raci } \\
\text { kan }\end{array}$ & 9 & 118 & 13 & $\begin{array}{c}\leq 60 \\
\text { Menit }\end{array}$ \\
\hline Non & 21 & 139 & 6 & $\leq 30$ \\
\hline
\end{tabular}

\begin{tabular}{lc}
\hline Raci & Menit \\
kan & \\
\hline
\end{tabular}

Tabel 5.23 Waktu Tunggu Resep Puskesmas Natai Pelingkau

\begin{tabular}{|c|c|c|c|c|}
\hline \multirow[b]{2}{*}{$\begin{array}{c}\text { Jenis } \\
\text { Rese } \\
\text { p }\end{array}$} & \multirow[b]{2}{*}{$\begin{array}{c}\text { Juml } \\
\text { ah } \\
\text { Rese } \\
\text { p }\end{array}$} & \multirow{2}{*}{$\begin{array}{c}\text { Juml } \\
\text { ah } \\
\text { Wak } \\
\text { tu } \\
\text { Tung } \\
\text { gu } \\
\text { (Me } \\
\text { nit) }\end{array}$} & \multicolumn{2}{|c|}{$\begin{array}{c}\text { Rata-Rata } \\
\text { Waktu Tunggu } \\
\text { (Menit) }\end{array}$} \\
\hline & & & $\begin{array}{c}\text { Dari } \\
\text { Hasil } \\
\text { Peneli } \\
\text { tian }\end{array}$ & $\begin{array}{c}\text { Standa } \\
\text { r } \\
\text { Pelaya } \\
\text { nan } \\
\text { Minim } \\
\text { al }\end{array}$ \\
\hline $\begin{array}{l}\text { Raci } \\
\text { kan }\end{array}$ & 11 & 142 & 13 & $\begin{array}{c}\leq 60 \\
\text { Menit }\end{array}$ \\
\hline $\begin{array}{l}\text { Non } \\
\text { Raci } \\
\text { kan }\end{array}$ & 19 & 116 & 6 & $\begin{array}{c}\leq 30 \\
\text { Menit }\end{array}$ \\
\hline
\end{tabular}
membandingkan waktu tunggu obat racikan dan non racikan antara 2 Puskesmas. Terdapat perbedaan waktu tunggu pelayanan resep untuk obat jadi di Puskesmas Sungai Rangit dan Puskesmas Natai Pelingkau. Waktu tunggu pelayanan resep obat non racikan di Pusekesmas Sungai Rangit memiliki rata- rata pengerjaan selama 6,6 menit dan Puskesmas Natai Pelingkau memiliki rata - rata pengerjaan resep 6,1 menit. Untuk pengerjaan obat racikan di Puseksmas Sungai Rangit memiliki rata - rata waktu pengerjaan 13,1 menit sedangkan untuk pengerjaan obat racikan di Puskesmas Natai Pelingkau rata-rata waktu pengerjaan 12,9 menit.

Beberapa faktor yang dapat mempengaruhi waktu tunggu pelayanan resep. Faktor pertama adalah jumlah petugas pelayanan kefarmasian di Puskesmas. Faktor kedua, jumlah obat yang diracik pada obat racikan serta banyak tidaknya resep yang masuk mempengaruhi 
waktu tunggu pelayanan resep. Ketiga adalah sarana dan prasarana termasuk penggunaan teknologi komputer dalam pelayanan resep.

Beberapa faktor penyebab ke 1 yaitu lamanya waktu tunggu pelayanan resep adalah faktor sumber daya manusia atau petugas kefarmasian di Puskesmas dari segi kuantitas dan kualitas di kedua puskesmas sudah memadai, banyak atau sedikitnya tenaga kefarmasian di Puskesmas sangat mempengaruhi kecepatan pelayanan resep.

Pada Faktor ke 2 yang mempengaruhi waktu tunggu adalah jumlah obat yang dibuat serta banyak tidaknya resep yang masuk mempengaruhi waktu tunggu pelayanan resep. Semakin banyak jumlah komponen obat dalam satu resep serta semakin banyak resep yang masuk pada waktu yang hampir bersamaan maka semakin lama pula petugas farmasi dalam melayani resep obat. Resep yang menumpuk menjadi faktor penentu obat lama diserahkan pada pasien.

Faktor lain yang dapat mempengaruhi lamanya waktu tunggu adalah ruang pelayanan yang sempit menambah lamanya waktu tunggu pelayanan obat.

Berdasarkan hasil pengamatan yang dilakukan di Puskesmas Sungai Rangit, luas ruang pelayanan kefarmasian cukup luas untuk pelayanan resep, sehingga ruang peracikan berada 1 ruangan dengan pelayanan resep namun disisi yang berbeda. Sedangkan untuk prasarana yang tersedia terdiri dari 3 buah meja, rak penyimpanan obat, dan perlatan peracikan obat. Untuk bagian penerimaan resep obat masih dikerjakan secara manual dan belum ada sistem komputer untuk input data serta mengeluarkan print out dan untuk tenaga kefarmasian berjumlah 3 orang yang terdiri dari 1 Apoteker dan 2 Asisten Apoteker

Berdasarkan hasil pengamatan di Puskesmas Natai Pelingkau, jumlah tenaga kefarmasian berjumlah 3 orang yang terdiri dari 1 Apoteker dan 2 Asisten Apoteker, dan untuk luas ruang pelayanan kefarmasian masih kurang luas untuk pelayanan resep, ruang menjadi sempit dikarenakan ruang peracikan berada satu ruangan dengan pelayanan resep namun disisi berbeda, dan prasarana tidak jauh berbeda dari Puskesmas Sungai Rangit, prasarana yang tersedia bagi pelayanan kefarmasian di Puskesmas Natai Pelingkau adalah meja pelayanan dan meja kasir yang bersebelahan, rak penyimpanan obat, dan meja peracikan obat.

\section{KESIMPULAN}

1. Hasil penelitian tentang Tingkat Kepuasan Pasien Terhadap Pelayanan Kefarmasian di Puskesmas Sungai Rangit dan Puskesmas Natai Pelingkau Kabupaten Kotawaringin Barat menunjukkan bahwa tingkat kepuasan terbesar pada dimensi Kehandalan (78\%) pada Puskesmas Natai Pelingkau dan (78\%) pada Puskesmas Sungai Rangit, selanjutnya pada dimensi ketanggapan (82\%) pada Puskesmas Natai Pelingkau dan (81\%) pada Puskesmas Sungai Rangit, dimensi jaminan (86\%) pada Puskesmas Natai Pelingkau dan (85\%) pada Puskesmas Sungai Rangit, dimensi Empati (82\%) pada Puskesmas Natai Pelingkau dan (82\%) pada Puskesmas Sungai Rangit, 
Kemudian terakhir pada dimensi Bukti Fisik (83\%) dan (83\%) pada Puskesmas Sungai Rangit dan Natai Pelingkau, sehingga persentase rata - rata tingkat kepuasan pasien di Puskesmas Sungai Rangit dan Puskesmas Natai Pelingkau Kabupaten Kotawaringin Barat Secara keseluruhan sebesar (82\%) pada Puskesmas Sungai Rangit dan (82\%) Pada Puskesmas Natai Pelingkau dengan kategori kepuasan adalah sangat puas.

2. Berdasarkan hasil penelitian yang dilakukan di pelayanan kefarmasian Puskesmas Sungai Rangit dan Puskesmas Natai Pelingkau tentang waktu tunggu pelayanan resep dapat disimpulkan bahwa rata - rata waktu tunggu yang dibutuhkan untuk menyelesaikan resep racikan adalah 13 menit pada kedua Puskesmas yaitu Puskesmas Sungai Rangit dan Puskesmas Natai Pelingaku, sedangkan waktu tunggu pelayanan resep obat non racikan adalah 6 menit pada Puskesmas Sungai Rangit dan 6 Menit pada Puskesmas Natai Pelingkau. Hal ini menunjukan bahwa rata - rata waktu tunggu pelayanan resep di kedua puskesmas telah memenuhi Standar Pelayanan Minimal yang menerangkan bahwa untuk resep racikan $\leq 60$ menit dan resep obat non racikan $\leq 30$ menit.

\section{SARAN}

1. Berdasarkan kesimpulan pada hasil penelitian ini, maka saran untuk Puskesmas Sungai Rangit dan Puskesmas Natai Pelingkau perlu mempertahankan kepuasan pasien terhadap pelayanan pada seluruh dimensi, walaupun nilai persentase di kedua Puskesmas telah mencapai kategori sangat puas.

2. Keramahan petugas kefarmasian harus lebih diperhatikan sebab hal ini juga termasuk pandangan pasein yang sangat penting agar pasien senang berobat di puskesmas dan mau datang berobat kembali.

3. Bagi peneliti selanjutnya dapat melakukan penelitian pada bidang yang sama di Puskesmas lainnya.

\section{DAFTAR PUSTAKA}

Adila Prabasiwi, dkk. 2019. Waktu Tunggu Pelayanan Resep di Dua Puskesmas Kabupaten Tegal: Kota Tegal.

Depkes RI. 2016. Pusat Data dan Informasi Kementrian

Kesehatan Republik

Indonesia : PUSDATIN

KEMKES. Jakarta.

Emilia, S. 2016. Gambaran Tingkat

Kepuasan di UPT Puskesmas

Sindang Jawa Kabupaten

Cirebon: Jakarta.

Erizal, Dr. Ir. MAgr. 2015, Pengantar Monitoring Pengendalian Proyek

Hendra, S. dkk. 2018. Tingkat Kepuasan Pasien Terhadap Pelayanan Kefarmasian di Puskesmas Doi-Doi Kecamatan Pujanating Kabupaten Barru: Makasar.

Handayani, S. 2016. Tingkat Kepuasan Pasien Terhadap Pelayanan Kesehatan di Puskesmas Baturetno: Wonogiri.

Kesuma, Pradipta Bagus. 2017. Pemberdayaan Pedagang Kaki Lima (Study Tentang Pemberian Fasilitas Pemkot Blitar Terhadap Pkl). Diss. 
University

Muhammadiyah Malang.

Kotler, Philip and Kevin Lane Keller, 2016. Marketing Managemen, 15 th Pearson Education, inc,

Menkes RI. 2016. Peraturan Menteri Kesehatan RI Nomor 74 Tahun 2016 Tentang Standar Pelayanan Kefarmasian di Puskesmas.

Menkes RI. 2014. Peraturan Menteri

Kesehatan RI Nomor 35

Tahun 2014 Tentang Standar Pelayanan Kefarmasian di Apotek.

Nurma, KP. dkk. 2017. Analisis Waktu Tunggu Pelayanan Resep Pasien Rawat Jalan di Depo Farmasi Gedung MCEB RS Islam Sultan Agung: Semarang.

Nursalam. 2017. Metodologi Penelitian Ilmu

Keperawatan: Pendekatan Praktis. (P. P. Lestari, Ed.) (4th ed.). Jakarta: Salemba Medika.

Permenkes. 2019. Peraturan Tentang

Puskesmas No.43 tahun 2019

: Jakarta

Purba, Dame TIka O. 2015. Tingkat Kepuasan Pasien Terhadap Peayanan Kesehatan Di Puskesmas Huta Rakyat Kecamatan Sidikalang Kabupaten Dairi : Universitas Sumatera Utara.

Prabasiwi A, Prabandari S, Dewi A.K.2018.Waktu Tunggu Pelayanan Resep di Dua Puskesmas Kabupaten Tegal :Pemikir

Pohan IS, 2014. Jaminan Mutu Layanan Kesehatan. Jakarta: EGC.
Permana, AA. 2018. Evaluasi Waktu

Tunggu dan Kepuasan Pelayanan Pada Pasien Rawat Jalan di RSUD Dr.Loekmono Hadi Kudus: Surakarta.

Pipintri Margiluruswati, L.I. 2017. Analisis Ketepatan Waktu Tunggu Pelayanan Resep Pasien JKN Dengan Standar Pelayanan Minimal Rumah Sakit: Surabaya.

Ratih, PR. 2017. Evaluasi Kepuasan Pasien Terhadap Pelayanan Farmasian di Apotik " $x "$ " Banjarmasin.

Rabiatul, A. 2018. Tingkat Kepuasan Pasien Terhadap Pelayanan Kefarmasian di Puskesmas Pahandut: Palangkaraya.

Rizqiana, AD. 2015. Gambaran Kualitas Pelayanan Kesehatan di Puskesmas Sedan Kabupaten Rembang Jawa Tengah: Jakarta.

Rina Feteriyani, dkk. 2018. Tingkat Kepuasan Pasien Puskesmas Pekauman Banjarmasin Terhadap Pelayanan Kefarmasian: Banjarmasin.

Rahmayanti, dan Ariguntar, Tri. $2017 . \quad$ Karakteristik

Responden dalam

Penggunaan Jaminan

Kesehatan Pada Era BPJS di Puskesmas Cisoka Kabupaten Tangerang Januari-Agustus $2015 . \quad$ Jurnal Medicoeticolegal dan Manajemen Rumah Sakit. Vol 6, No.1: 61-65

Sugiyono. 2017. Metode Penelitian Kuantitatif Kualitatif dan R\&D. Bandung Alfabeta.

Santriatsi Maria. 2017. Tingkat Kepuasan Pasien Terhadap Pelayanan Kefarmasian Di Puskesmas Oepoi. Politeknik 
Kesehatan Kemenkes :

Kupang.

Sukamto Herlinda, 2017. Evaluasi

Kepuasan Pasien Terhadap

Pelayanan Kefarmasian Di Apotek Rawat Jalan RSUP dr.Wahidin Sudirohusodo. Program Studi S1 Farmasi UIN Alauddin : Makasar.

Siregar, Sri Endang. 2018.Waktu tunggu pelayanan resep rawat jalan di instalasi farmasi rumah sakit : Sumatera Utara

Sugiyono, 2014.Statistik Untuk Penelitian. Alfabeta : Bandung

Talinati, 2017. Survey kepuasan pasien terhadap pelayanan kefarmasian di puskesmas oesao periode Juni-Juli 2016: Karya Tulis Ilmiah. Program Studi Farmasi Poltekkes Kemenkes Kupang. 